\title{
Size Variability in Seed Lot Impact Seed Nutritional Balance, Seedling Vigor, Microbial Composition and Plant Performance of Common Corn Hybrids
}

\author{
Saveetha Kandasamy ${ }^{1, *}$, Nimalka Weerasuriya ${ }^{1,2}$, Daniella Gritsiouk ${ }^{1,2}$, Greg Patterson ${ }^{1}$, \\ Soledad Saldias ${ }^{1}$, Shimaila Ali ${ }^{1}$ and George Lazarovits ${ }^{1,2}$ \\ 1 A\&L Biologicals, Agroecological Research Services Centre, London ON N5V 3P5, Canada; \\ nweerasu@uwo.ca (N.W.); dgritsio@uwo.ca (D.G.); patterson@alcanada.com (G.P.); \\ saldias@alcanada.com (S.S.); shimaila@alcanada.com (S.A.); lazarovitsg@alcanada.com (G.L.) \\ 2 Department of Biology, University of Western Ontario, London ON N6A 3K7, Canada \\ * Correspondence: saveetha@alcanada.com; Tel.: +1-(519)-457-2575 (ext. 224)
}

Received: 12 December 2019; Accepted: 20 January 2020; Published: 22 January 2020

\begin{abstract}
Soils with highly uniform textural, physical, and chemical characteristics still give rise to crop stand variability. Seed quality is one of the factors adding to yield variability and has become a concern for corn growers. Hybrid seed producers claim that their seeds provide a uniformity in crop emergence and productivity, but they do not always provide detailed studies to support this claim. Based on growers' concerns, we examined fields planted with three different hybrid varieties and found that $25 \%$ to $50 \%$ of the stand had relatively weak vigor, where seed variety A showed $15 \%$ of seedlings with lower vigor, and varieties $B$ and $C$ had $30 \%$ of seedlings with low vigor. These apparent differences in plant vigor prompted us to initiate a cursory investigation to identify how seed size influenced seedling vigor and if the seedling's microbial profile played a role in the early growth stages of three commonly grown corn hybrids in Ontario. Seeds were separated based on size, prior to conducting a growth room study. Different sizes of seeds from the same seed lot showed significant differences in vigor capacity and related biometric components. Significant differences were also found in their nutritional composition and microbial profiles within the different seed sizes and the roots and shoots of seedlings derived from such seeds. The results clearly indicate that seed size greatly impacts the plant growth and its microbiome, resulting in seedlings with different plant vigor, microbiomes, and performance.
\end{abstract}

Keywords: seed size; seedling vigor; nutrient content; microbiome; diversity index; corn hybrids

\section{Introduction}

The use of hybrid seeds with high seed quality is an important component of modern agriculture for successful crop production [1]. Uniform crop establishment is a key component for achieving a good crop yield potential and ensuring profitability. However, the yield potential of an average corn hybrid has a $10 \%$ to $25 \%$ variance in growth consistency and yield in comparison to the highest yielding hybrid groups on the market due to their size variation within the seed lot [2]. In choosing which hybrid seed variety to plant, factors such as ear size, rows of kernels, and big or deep kernels do not guarantee high productivity [2]. Seed size is widely accepted as a measure of seed quality, which can affect germination percentage, seedling vigor, plant competition with the competing weed species, grain yield and the produced grain quality [3].

The effect of seed size on the uniformity of emergence, seedling vigor and the quality of produced seeds have been studied in many crops [4-6]. Large chickpea seeds produced significantly higher yield and at the same time seed size had no impact on lentil [4]. Larger seed size produced high vigor 
seedlings, resulting in $16 \%$ increased grain yield compared with plants produced from small seeds [6]. Spring wheat plants derived from larger seeds had higher seedling vigor and had larger plant growth factors such as number of spikes produced, biomass, and grain yield, relative to plants derived from smaller seeds under a range of wild oat densities [7]. Larger seeds produced high vigor seedlings in different seeding rates of barley under various field conditions [8]. In contrast, the seed's size had very little effect on yield of rape seed [9].

Seed vigor is reflected by the rapid and uniform emergence of seedlings, field establishment, and plant performance [10,11]. High seed vigor enhances the ability to obtain optimal plant densities and high crop yields [12]. There are no government or industry standard tests that measure seed vigor and seed factors that may be used to evaluate vigor. Growers mostly rely on in-house testing and the reputation of seed companies to choose their hybrid varieties [12]. Unfortunately, seed and seedling vigor among different hybrids can vary significantly $[1,10]$ and these differences impact a hybrid's ability to germinate and grow rapidly under varying stressful conditions. However, the seed vigor differences induced by lower quality seeds within the seed lot of similar hybrids are more than genetic differences in hybrids [2].

Seedling vigor is significantly influenced by seed weight and/or size [12,13]. Zhang et al. [13] measured four indicators for seedling vigor (seedling shoot length, root length, wet weight, and dry weight) and found that 57 of 65 quantitative trait loci (DNA correlating to variations in phenotypes) corresponded to seedling vigor. Several studies show differences between high and low seed vigor, and the effect of varying vigor on rapid, uniform seedling emergence in a plot [12]. However, previous studies on the effect of seed vigor on plant growth and productivity have focused on the physical and physiological characteristics of high and low vigor seeds [12], and have scarcely examined the microbial communities that may influence seed and seedling vigor.

The composition of microbial communities on and within seeds may affect their storage and field performance, whether these microbes are indigenous or applied as biocontrol agents [1]. Plant microbiomes play an integral role in plant vigor and health, and most microorganisms colonize all tissues of a plant [14]. Biswas et al. [15] studied effects of several diazotrophic bacteria on rice seedling vigor via rhizobial inoculations. There were observed changes in the rate of seedling emergence, radical elongation, height and dry matter, plumule length, cumulative leaf and root areas, grain and straw yields. Gholami et al. [16] studied the effect of various plant growth-promoting rhizobacteria (PGPR) on seed germination, seedling growth, and yield of field-grown maize and found that the inoculation of maize seeds with PGPRs showed a significant enhancement of seed germination and seedling vigor and their related biometrics.

The amount of stored protein, quality of mRNA, growth performance of the mother plant, environmental factors during seed development, and the supply of all essential mineral elements to seeds are all key determinants of successful germination and seed vigor [17,18]. Studies have focused on optimization of seed nutrition through fertilizer applications, seed coating, and seed priming [19], but there is no information available on the interaction of all the biochemical parameters of the seed nutrients, endophytic microbiome of the seeds, and how they relate to seed germination and vigor. Therefore, the present study set out as a preliminary investigation of the relationship between seed nutrient content and microbiome composition with seedling vigor by categorizing three common corn hybrids, (1) P9998AMXT, (2) P0157AMXT, and (3) DKC48-56 RIB, based on their size. The microbial transfer from seed to seedling and the effect of seed size on the microbial transfer to the seedling was also investigated.

\section{Materials and Methods}

\subsection{Corn Growth Room Assay}

One seed lot from three corn hybrid varieties, provided by a grower, were grouped into the following seed size categories: (1) variety P9998AMXT; small (V1-S 0.2 g), medium (V1-M 0.3 g), large (V1-L 0.4 g), (2) variety P0157AMXT; medium (V2-M 0.2 g), large (V2-L 0.3 g) and (3) variety DKC48-56 RIB; medium (V3-M 0.3 g), large (V3-L 0.35 g). These seed lots were freshly purchased by 
the grower from the seed producer and stored in the same warehouse according to the producer's storage specifications. Individual and average seed weights for each category were recorded. Five replicate 20 $\mathrm{cm}$-diameter pots were sown with five seeds from each category at a uniform depth using Miracle-Gro Moisture Control Potting mix (to avoid differences in soil factors on emergence). Plants were grown at $16 / 8$ h day-night cycle at $20-25{ }^{\circ} \mathrm{C}$ with $45-55 \%$ relative humidity. Upon germination, seedlings were watered daily for four weeks, after which the growth room trial was terminated. At the time of harvest, the plants were photographed, and their biometric parameters were recorded. The vigor index was calculated using the formulas proposed by Abdul-Baki [20]: VI-1 $=$ Seedling length $\times$ Germination $\%$, and VI-2 $=$ Seedling Dry Weight $\times$ Germination $\%$. Root and shoot samples were collected and stored at $-20{ }^{\circ} \mathrm{C}$ for analysis of microbial communities. The experiment was repeated twice to test the accuracy and the reproducibility of results.

\subsection{Yield Loss Potential Calculations}

Each variety's total yield loss potential (\%) was calculated in four steps, using the contribution $\%$ for each seed size within a lot and their respective Vigor index-2 values. For each seed size, the contribution $\%$ is calculated using:

$$
\text { contribution } \%=\frac{\text { number of seeds }}{\text { total seeds }} \times 100 .
$$

The yield loss potential (\%) for each seed size within a lot was calculated:

$$
\begin{aligned}
& \text { yield potential } \%=\frac{\sum \text { contribution } \%}{\text { maximum VI }} \times \text { mean VI, } \\
& \text { yield loss potential } \%=100-\text { yield potential } \%,
\end{aligned}
$$

where, VI is the vigor index-2 (VI-2) value for each seed size, and the $\sum$ contribution (\%) is 100 for each variety. The contribution to yield loss (\%) for each seed size within a hybrid variety was determined:

$$
\text { contribution to yield loss } \%=\text { contribution } \% \times \text { yield loss potential } \% \text {. }
$$

Finally, potential variety yield loss (\%) was determined for each variety by summing the contributions to yield loss (\%) for each seed size within a hybrid variety:

$$
\text { potential variety yield loss } \%=100-\sum \text { contribution to yield loss } \% \text {. }
$$

\subsection{Seed Nutritional Profiling}

All samples ( $n=7$ with 5 replicates) were analyzed for their nutritional composition from each of the two-repeated experiments. The chemical parameters included Ash (\%), Acid Detergent Fiber $(\mathrm{ADF})(\%)$, Fat $(\%)$, Starch (\%), Crude protein (\%), Water Soluble Sugars (WSS) $(\%), \mathrm{pH}$, Nitrate Nitrogen $\left[\mathrm{NO}_{3}-\mathrm{N}\right](\mathrm{ppm})$, Phosphorus [P] (\%), Potassium [K] (\%), Magnesium [Mg] (\%), Calcium [Ca] $(\%)$, Sulphur [S] (\%), Boron [B] ( $\mu \mathrm{g} / \mathrm{g})$, Copper [Cu] $(\mu \mathrm{g} / \mathrm{g})$, Iron [Fe] $(\mu \mathrm{g} / \mathrm{g})$, Manganese [Mn] $(\mu \mathrm{g} / \mathrm{g})$, Zinc $[\mathrm{Zn}](\mu \mathrm{g} / \mathrm{g})$, Aluminum [Al] $(\mu \mathrm{g} / \mathrm{g})$, Chloride [Cl] $(\%)$, and Sodium $[\mathrm{Na}](\%)$. Briefly, the samples were processed by passing through a Retsch ZM 200 grinding mill (Retsch $\mathrm{GmbH}$ ), equipped with a 1 $\mathrm{mm}$ cutting screen to reduce the particle size and homogenize samples. Element concentrations were measured using inductively coupled plasma mass spectrometry (ICP) and others using the standard analytical methodologies of A \& L Canada Laboratories (London, ON, Canada).

\subsection{Bacterial Community DNA Extraction and TRFLP Analysis}

Microbial community DNA of corn seed, root, and shoot samples were extracted using the Soil DNA Isolation Kit (Norgen Biotek Corporation, Thorold, ON, Canada) as per the 
manufacturer's instructions with minor modifications and were analyzed via T-RFLP of the conserved 16S-rRNA gene. Fluorescently-labelled universal bacterial FAM-labelled forward 63F (5'-CAGGCCTAACACATGCAAGTC-3') [21] and VIC-labelled reverse 1389R (5'-ACGGGCGGTGTGTA CAAG-3') [22] primers were used for amplification. PCR reactions were carried out using the following conditions: initial denaturation at $94{ }^{\circ} \mathrm{C}$ for $5 \mathrm{~min} ; 29$ cycles of denaturation at $94{ }^{\circ} \mathrm{C}$ for $45 \mathrm{~s}$, primer annealing at $56^{\circ} \mathrm{C}$ for $45 \mathrm{~s}$, elongation at $72{ }^{\circ} \mathrm{C}$ for $2 \mathrm{~min}$; and a final extension at $72{ }^{\circ} \mathrm{C}$ for $10 \mathrm{~min}$. The PCR mixture comprised of $25 \mu \mathrm{L} 2 X$ Master Mix, $1 \mu \mathrm{L}$ primer, with either $1.5 \mu \mathrm{L}$ of shoot, $2 \mu \mathrm{L}$ of root, or $2 \mu \mathrm{L}$ of seed DNA, and was topped up to $50 \mu \mathrm{L}$ using PCR grade water. A negative control was made using a PCR amplification mixture with no template DNA.

PCR products were purified and digested for $3 \mathrm{~h}$ at $37^{\circ} \mathrm{C}$ using a mixture of $0.5 \mu \mathrm{L} 5 \mathrm{U}$ HhaI restriction enzyme (New England Biolabs, Ipswich, MA, USA), $2.5 \mu \mathrm{L}$ of Cutsmart Buffer (New England Biolabs, Ipswich, MA, USA) and $10 \mu \mathrm{L}$ of PCR grade water. HhaI enzyme was chosen for this study based on our previous work done comparing other enzymes widely used in TRFLP analysis. This provided most reproducible and robust profiles among others tested.

The digested fluorescently labelled terminal restriction fragments (TRFs) were separated and detected via capillary electrophoresis (Applied Biosystems 3730 DNA Analyzer). Using GeneMarker ${ }^{\circledR}$ software V2.2.0, the length of TRFs (in base pairs) were determined in comparison to internal GSI 200 LIZ size standard (1200 bp), with a base pair size cut-off range of 1 to 2000 and fluorescent unit peak intensity detection range of 50 to 50,000 . Intensity data from GeneMarker ${ }^{\circledR}$ was exported to XLSTAT 2013 software and the abundance of each TRF was determined by measuring the fluorescence unit and the diversity using binary numbers. Each biological replicate sample was analyzed in duplicate. Peaks were identified using an established internal bacterial TRF database made using in-silico analysis (digested with HhaI enzyme using NEBcutter V2.0; online tool) of the 16S rRNA gene sequences of about 1000 bacterial strains isolated and identified from the rhizosphere, root, and endosphere of corn and wheat. The database has been further confirmed by digesting the corresponding sequences retrieved from NCBI database [23].

\subsection{Statistical Analysis}

MS Excel Stat 2016 was used to calculate the means and standard errors of the biometric data and significance of differences were analyzed within each variety via analysis of variance (one-way ANOVA), and means were compared using Duncan's mean comparison (DMRT) using R v.3.6.1. PCAs and scatterplots were created by analyzing co-variance in XLSTAT to compare and visualize the differences in the diversity of microbial communities at 95\% confidence level $(p<0.05)$. Alpha diversity indices (Shannon, Simpson, and Fisher) were calculated from TRFLP profiles using vegan [24] in R v3.6.1 within RStudio, the ALDEx2 package [25] was used to identify influential TRFLPs, vegan was used to do NMDS statistical testing on seed biometric and chemical metadata, and the gplots package [26] was used to make TRF heatmaps.

\section{Results}

A visual comparison of plant vigor from different seed size categories within each seed lot are presented in Figure 1. The V1-L (Figure 1A), V2-L (Figure 1B), and V3-M (Figure 1C) seeds had higher vigor in their respective seed lot categories.

\subsection{Seed Sizes}

Seeds from three corn hybrids were split into different categories based on size: small/medium/large in P9998AMXT (Variety-1/V1), medium/large in P0157AMXT (Variety-2/V2) and medium/large in DKC48-56RIB (Variety-3/V3). There was no significant portion of small seeds in V2 and V3 $(<3 \%$ contribution to the seed lot, $p>0.05$ ). The individual and average seed weights of each category were recorded, and the number (and percent) of seeds in $100 \mathrm{~g}$ from each category was counted. Average seed weights ranged from $0.17-0.45 \mathrm{~g}$ in V1, 0.17-0.32 $\mathrm{g}$ in V2 and $0.29-0.37 \mathrm{~g}$ in V3 (Figure 2A). In a $100 \mathrm{~g}$ lot of V1, $21.56 \mathrm{~g}$ (91 seeds; 31\%) were small, $21.65 \mathrm{~g}$ (62 seeds; $21 \%$ ) were medium and $56.68 \mathrm{~g}$ 
(142 seeds; 48\%) were large. Variety 2 had two sizes of seeds: $17.42 \mathrm{~g}$ (83 seeds; 21\%) were medium and $82.43 \mathrm{~g}$ (314 seeds; 79\%) were large. Variety 3 had two sizes of seeds: $9.63 \mathrm{~g}$ (32 seeds; 10.5\%) were medium and $90.54 \mathrm{~g}$ (273 seeds; 89.5\%) were large.

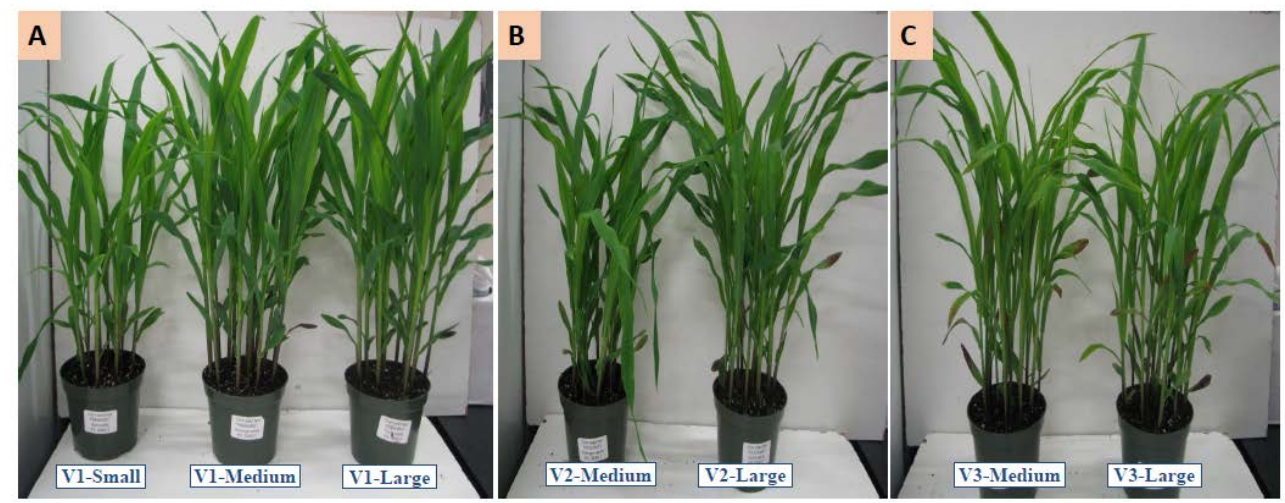

Figure 1. Four-week-old hybrid corn seedlings. (A) Variety 1 (from left to right: small, medium, and large); (B), Variety 2 (from left to right: medium and large); (C), Variety 3 (from left to right: medium and large).

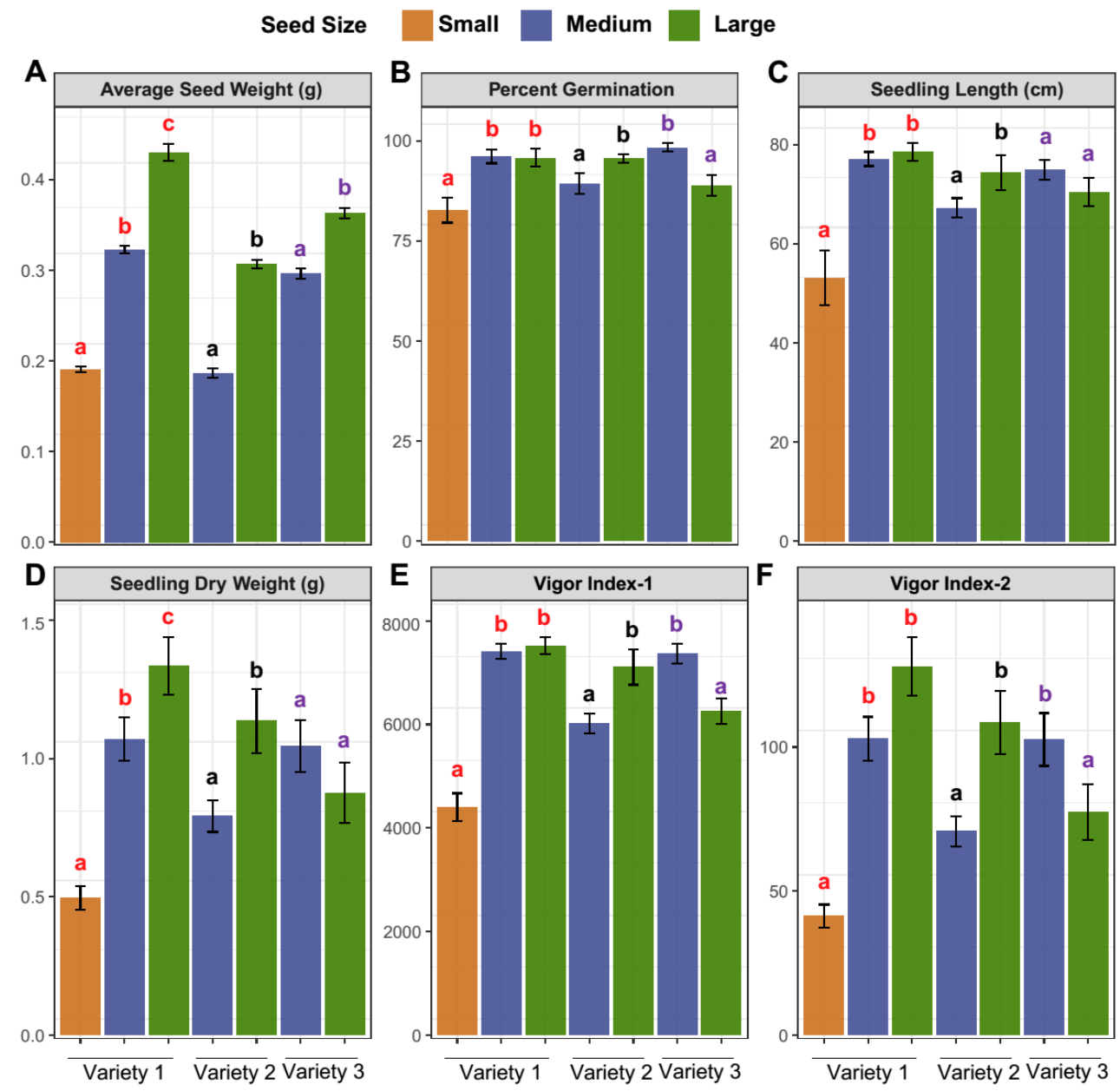

Figure 2. Biometric analysis of different seed size categories (small, medium, large) of the three hybrid corn varieties. Average seed weight $(\mathrm{g})(\mathrm{A})$, percent germination $(\mathbf{B})$, seedling length $(\mathrm{C})$, seedling dry weight (D), vigor index-1 (E), vigor index-2 (F). The means of different seed size categories are compared with in the variety. Means followed by the same letter in each category do not statistically differ from one other according to DMRT at 5\% $(p<0.05)$ probability level. 


\subsection{Biometric Measurements}

There is a large variance in the vigor and germination capabilities of seeds in each seed lot. The average germination percentage of seeds ranged from $83 \%$ to $98 \%$, with the recorded lowest germination $(82 \%)$ in small V1 seeds. There is no difference in germination percentage between the seed sizes of V1 medium and large seeds; both had $96 \%$ germination. The large seeds of V2 showed better germination than the medium sized seeds (96\% vs. $89 \%$ ) whereas the V3 medium seeds had higher germination than the large seeds (98\% vs. $88 \%$ ) (Figure $2 \mathrm{~B}$ ). Other biometric parameters such as seedling length (Figure 2C), seedling dry weight (Figure 2D), Vigor index-1 (Figure 2E), and Vigor index-2 (Figure $2 \mathrm{~F}$ ), followed the same pattern as germination percentage. There was a $96 \%$ correlation (" $\rho$ " 0.96 with $p<0.05$ ) between VI-1 and VI-2, so we used VI-2 for all the downstream analyses. We calculated the yield loss potential of each seed lot from the maximum guaranteed yield potential (assumed seeds with maximum VI in each lot as 100) alongside all sub-calculations (see Section 2.2). When considering different proportions of seed sizes within a lot, the total yield loss potential of the 3 varieties were $25 \%, 7 \%$, and $22 \%$, respectively, from their original yield potential (Table 1 ).

Table 1. Potential yield loss calculations of three corn hybrid varieties based on seed size and vigor index-2 (VI-2).

\begin{tabular}{|c|c|c|c|c|c|c|c|}
\hline Variety & Variety Name & Size & $\begin{array}{c}\text { Contribution } \\
\text { to Seed Lot } \\
\%\end{array}$ & $\begin{array}{c}\text { Yield } \\
\text { Potential } \\
\%\end{array}$ & $\begin{array}{c}\text { Yield Loss } \\
\text { Potential } \\
\%\end{array}$ & $\begin{array}{l}\text { Contribution } \\
\text { to Yield } \\
\text { Loss } \%\end{array}$ & $\begin{array}{c}\text { Potential } \\
\text { Yield Loss } \\
\%\end{array}$ \\
\hline \multirow{3}{*}{1} & \multirow{3}{*}{ P9998AMXT } & Small & 31 & 30 & 70 & 21.08 & \multirow{3}{*}{25.28} \\
\hline & & Medium & 21 & 80 & 20 & 4.20 & \\
\hline & & Large & 48 & 100 & - & - & \\
\hline \multirow{3}{*}{2} & \multirow{3}{*}{ P0157AMXT } & Small & $<3 \%$ & - & - & - & \multirow{3}{*}{7.14} \\
\hline & & Medium & 21 & 66 & 34 & 7.14 & \\
\hline & & Large & 79 & 100 & - & - & \\
\hline \multirow{3}{*}{3} & \multirow{3}{*}{ DKC48-56RIB } & Small & $<3 \%$ & - & - & - & \multirow{3}{*}{22.38} \\
\hline & & Medium & 10.5 & 100 & - & - & \\
\hline & & Large & 89.5 & 75 & 25 & 22.38 & \\
\hline
\end{tabular}

\subsection{Seed Nutritional Profiling}

The chemical differences between seed sizes within a hybrid variety were greater than differences between varieties (Table 2). Small seeds in V1 had higher levels of NO3-N (0.08\%), K (0.40\%), S (0.16\%), $\mathrm{Zn}(23.04 \mu \mathrm{g} / \mathrm{g}), \mathrm{Cl}(27.71 \mu \mathrm{g} / \mathrm{g}), \mathrm{Al}(6.30 \mu \mathrm{g} / \mathrm{g})$, and $\mathrm{Na}(0.03 \%)$ but lower ash content $(0.30 \%), \mathrm{Fe}(10.8$ $\mu \mathrm{g} / \mathrm{g}), \mathrm{Mn}(5.21 \mu \mathrm{g} / \mathrm{g})$ in respective elements $(0.06 \%, 0.33 \%, 0.13 \%, 15.11 \mu \mathrm{g} / \mathrm{g}, 9.30 \%, 5.54 \mu \mathrm{g} / \mathrm{g}, 0.02 \%$, $0.86 \%, 11.8 \mu \mathrm{g} / \mathrm{g}, 5.25 \mu \mathrm{g} / \mathrm{g})$ compared to V1-M and V1-L $(0.05 \%, 0.33 \%, 0.13 \%, 18.29 \mu \mathrm{g} / \mathrm{g}, 4.50 \%$, $4.43 \mu \mathrm{g} / \mathrm{g}, 0.02 \%, 1.11 \%, 40 \mu \mathrm{g} / \mathrm{g}, 6.33 \mu \mathrm{g} / \mathrm{g})$. In Variety 2, crude protein, $\mathrm{pH}$ and Iron were significantly different between medium $(9.57 \%, 6.18,35 \mu \mathrm{g} / \mathrm{g})$ and large seeds $(9.95 \%, 6.13,38 \mu \mathrm{g} / \mathrm{g})$. None of these parameters were significantly different between the medium and large size seeds in Variety 3, except Fe and Mn. In Variety 3, Fe and Mn are significantly lower in medium seeds (28 $\mu \mathrm{g} / \mathrm{g}$ and $5.29 \mu \mathrm{g} / \mathrm{g}$, respectively) compared to large $(49 \mu \mathrm{g} / \mathrm{g}$ and $6.92 \mu \mathrm{g} / \mathrm{g}$, respectively). Even though B levels are not significantly different, the levels positively correlate with vigor capacity of the seed categories in all the hybrids. 
Table 2. Seed chemical profile of the three corn hybrid varieties.

\begin{tabular}{|c|c|c|c|c|c|c|c|}
\hline Particulars & V1-Small & V1-Medium & V1-Large & V2-Medium & V2-Large & V3-Medium & V3-Large \\
\hline Ash (\%) & $0.30 \mathrm{a}$ & $0.86 \mathrm{~b}$ & $1.11 b$ & 1.58 & 1.69 & 1.20 & 1.02 \\
\hline Acid Detergent Fiber (ADF) (\%) & 2.73 & 3.20 & 2.83 & 2.68 & 2.94 & 3.38 & 3.39 \\
\hline Fat $(\%)$ & 3.51 & 3.14 & 3.14 & 3.62 & 3.52 & 3.80 & 3.89 \\
\hline Starch $(\%)$ & 58.77 & 57.27 & 60.10 & 59.59 & 58.27 & 57.21 & 57.09 \\
\hline Crude protein $(\%)$ & 10.78 & 10.92 & 11.51 & $9.57 \mathrm{a}$ & $9.95 b$ & 10.76 & 11.43 \\
\hline Water Soluble Sugars (WSS) (\%) & 2.61 & 2.86 & 2.81 & 2.80 & 2.98 & 3.18 & 3.37 \\
\hline $\mathrm{pH}$ & 6.12 & 6.11 & 6.11 & $6.18 \mathrm{a}$ & $6.13 b$ & 6.05 & 6.03 \\
\hline Nitrate Nitrogen $\left[\mathrm{NO}_{3}-\mathrm{N}\right](\%)$ & 0.08 & 0.06 & 0.05 & 0.06 & 0.06 & 0.07 & 0.07 \\
\hline Phosphorus $[\mathrm{P}](\%)$ & 0.32 & 0.28 & 0.31 & 0.30 & 0.29 & 0.31 & 0.32 \\
\hline Potassium $[\mathrm{K}](\%)$ & $0.40 \mathrm{a}$ & $0.33 b$ & $0.33 b$ & 0.32 & 0.30 & 0.34 & 0.34 \\
\hline Calcium [Ca] $(\%)$ & 0.03 & 0.02 & 0.03 & 0.03 & 0.03 & 0.03 & 0.03 \\
\hline Magnesium [Mg] (\%) & 0.11 & 0.10 & 0.12 & 0.10 & 0.11 & 0.11 & 0.12 \\
\hline Sulphur $[S](\%)$ & $0.16 \mathrm{a}$ & $0.13 b$ & $0.13 b$ & 0.11 & 0.11 & 0.14 & 0.14 \\
\hline Boron $[\mathrm{B}](\mu \mathrm{g} / \mathrm{g})$ & 1.49 & 1.61 & 1.91 & 1.20 & 1.33 & 1.48 & 1.32 \\
\hline Copper $[\mathrm{Cu}](\mu \mathrm{g} / \mathrm{g})$ & 2.22 & 2.77 & 2.15 & 1.89 & 2.20 & 2.70 & 2.92 \\
\hline Iron $[\mathrm{Fe}](\mu \mathrm{g} / \mathrm{g})$ & $10.8 \mathrm{a}$ & $11.8 \mathrm{~b}$ & $40 c$ & $35 a$ & $38 \mathrm{~b}$ & $28 \mathrm{a}$ & $49 \mathrm{~b}$ \\
\hline Manganese $[\mathrm{Mn}](\mu \mathrm{g} / \mathrm{g})$ & $5.21 \mathrm{a}$ & $5.25 a$ & $6.33 b$ & 3.35 & 3.62 & $5.29 a$ & $6.92 b$ \\
\hline Zinc $[\mathrm{Zn}](\mu \mathrm{g} / \mathrm{g})$ & $23.04 a$ & $15.11 b$ & $18.29 b$ & 16.35 & 16.69 & 21.86 & 22.64 \\
\hline Chloride [CL] (\%) & $27.71 \mathrm{a}$ & $9.30 \mathrm{~b}$ & $4.50 \mathrm{~b}$ & 12.34 & 14.46 & 12.87 & 11.79 \\
\hline Aluminum $[\mathrm{Al}](\mu \mathrm{g} / \mathrm{g})$ & $6.30 \mathrm{a}$ & $5.54 b$ & $4.43 c$ & $5.73 a$ & $3.98 b$ & 5.25 & 5.24 \\
\hline Sodium [Na] (\%) & 0.03 & 0.02 & 0.02 & 0.02 & 0.02 & 0.02 & 0.02 \\
\hline
\end{tabular}

Note: Significant differences were identified using one-way ANOVA, and a Duncan's Multiple Range Test confirmed differences between groups within each variety, where means with the same letter were not considered significantly different at $5 \%(p<0.05)$ probability level. 


\subsection{Microbial Profiling}

Principle component analysis of the Terminal Restriction Fragment Polymorphism (TRFLP) analyses of 16S-rRNA gene was carried out for the seeds, roots, and shoots of all the three hybrid corn varieties used in this study (Figures 3 and 4). Comparisons of the microbiomes of the seeds, roots and shoots that use TRFLP data from all seed sizes are shown in Figure 3. Variety 1 seeds and shoots shared a similar microbiome but were statistically different from the microbiomes of roots (Figure 3A). With Variety 2, the microbiomes of seeds, roots, and shoots were all statistically different (Figure 3B). In Variety 3, the shoot microbiome separated from the seed and roots, and a single point root outlier caused a slight overlap between seed and root clusters (Figure 3C). These results indicate that for each seed variety the microbiomes of the resulting plant tissues are more related to the genetics of the plant, with Variety 1 having a distinct pattern of separation in comparison to Varieties 2 and 3.
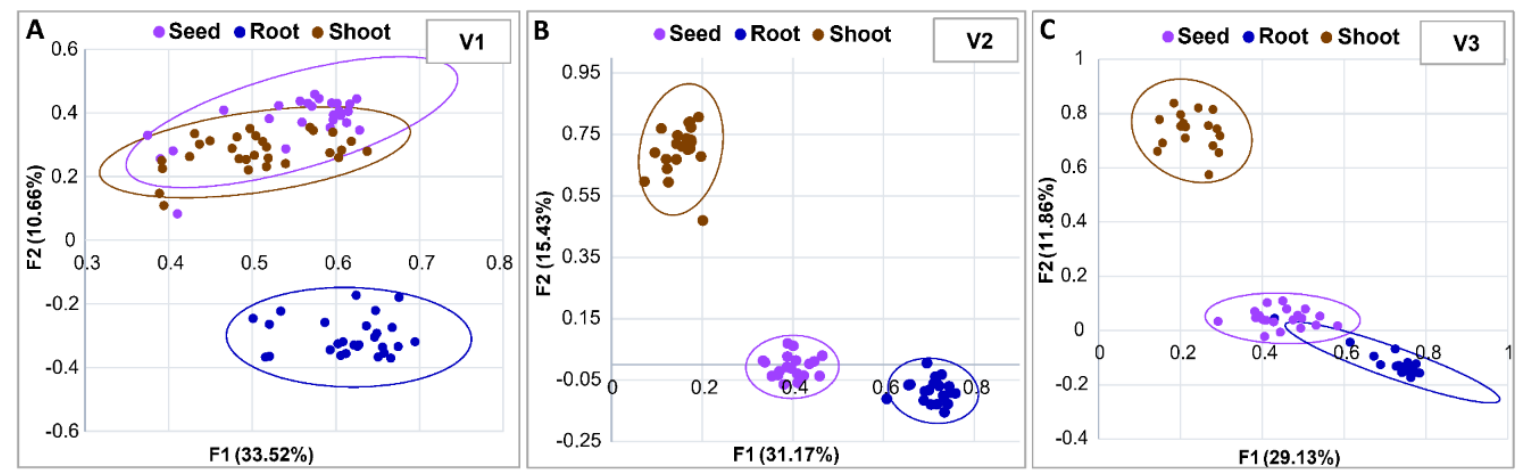

Figure 3. PCA biplots of microbial profiles of seed size categories (small, medium, and large), tissue types (seed, shoot and root), and varieties (V1, V2, V3) tested in this study generated using terminal restriction fragment length polymorphism (TRFLP). (A) Microbial profile of seed, root, and shoot in Variety 1; (B) Microbial profile of seed, root and shoot in Variety 2; (C) Microbial profile of seed, root and shoot in Variety 3. Nonoverlapping circles are statistically significant at $95 \%$ confidence level $(p<0.05)$ according to Bartlett's sphericity test. The further the distances between circles, the stronger the differences between the communities.

PCA analysis of the microbiomes of seeds by hybrid varieties showed that the microbiome separation of the seed of Variety 1 partitioned by seed size in significant manner (Figure 4A). Plants grown from the large seeds gave rise to root microbiomes that consistently segregated from that of small and medium seeds, the latter two being more similar but still significantly different from each other (Figure 4B). The shoots microbiomes derived from large seeds were also different from that of the shoots derived from medium and small seeds, which were very similar to each other (Figure 4C). With Variety 2, the TRFLP profiles of medium and large seeds were similar (Figure 4D) but separated within the plant's roots and shoots (Figure 4E,F). The opposite pattern was seen in Variety 3, where the TRFLP profiles of medium and large seeds were distinct (Figure 4G) but overlapped in the roots and shoots (Figure 4H,I). 


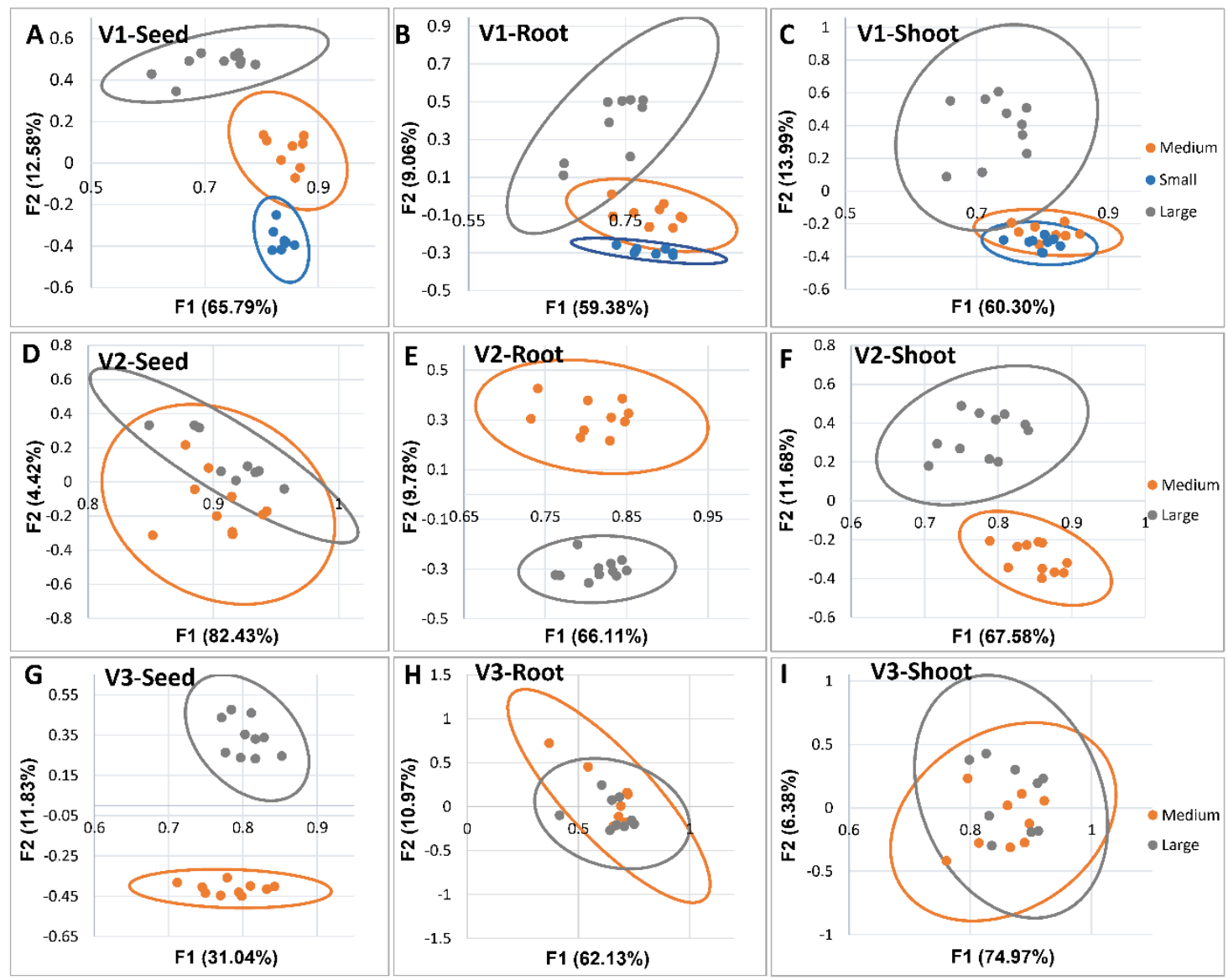

Figure 4. PCA biplots of seed, root, and shoot microbiome of three hybrid corn varieties. Each plot compares the microbial profiles of different seed categories (small, medium, and large) within each tissue type in every variety. V1-Seed (A), V1-Root (B), V1-Shoot (C), V2-Seed (D), V2-Root (E), V2-Shoot (F), V3-Seed (G), V3-Root (H), and V3-Shoot (I). Nonoverlapping circles are statistically significant at 95\% confidence level $(p<0.05)$ according to Bartlett's sphericity test. Further the distance (between circles) goes, the stronger the difference become among the communities.

\subsection{Probable Taxonomic Identities of Key Microbes}

Among the total TRFs detected, only a few were identified as being potential keystone taxa separating the seed size categories in each variety (Figure 5). Using TRFs with high effect sizes ( $>1$ or $<-1$ ) in ALDEx, the significant microbial drivers were plotted as a clustered heatmap (Figure 5). In general, there were more differences in TRF intensities (and communities) in Variety 1 than Varieties 2 and 3. The shoots of both Varieties 2 and 3 had distinct microbiomes compared to their respective seeds and roots. Variety 3 had a greater number of significant TRFs within seeds than Variety 2 ( 6 and 1, respectively), whereas large seeds of Variety 3 had half as many significant TRFs than Variety 2. 


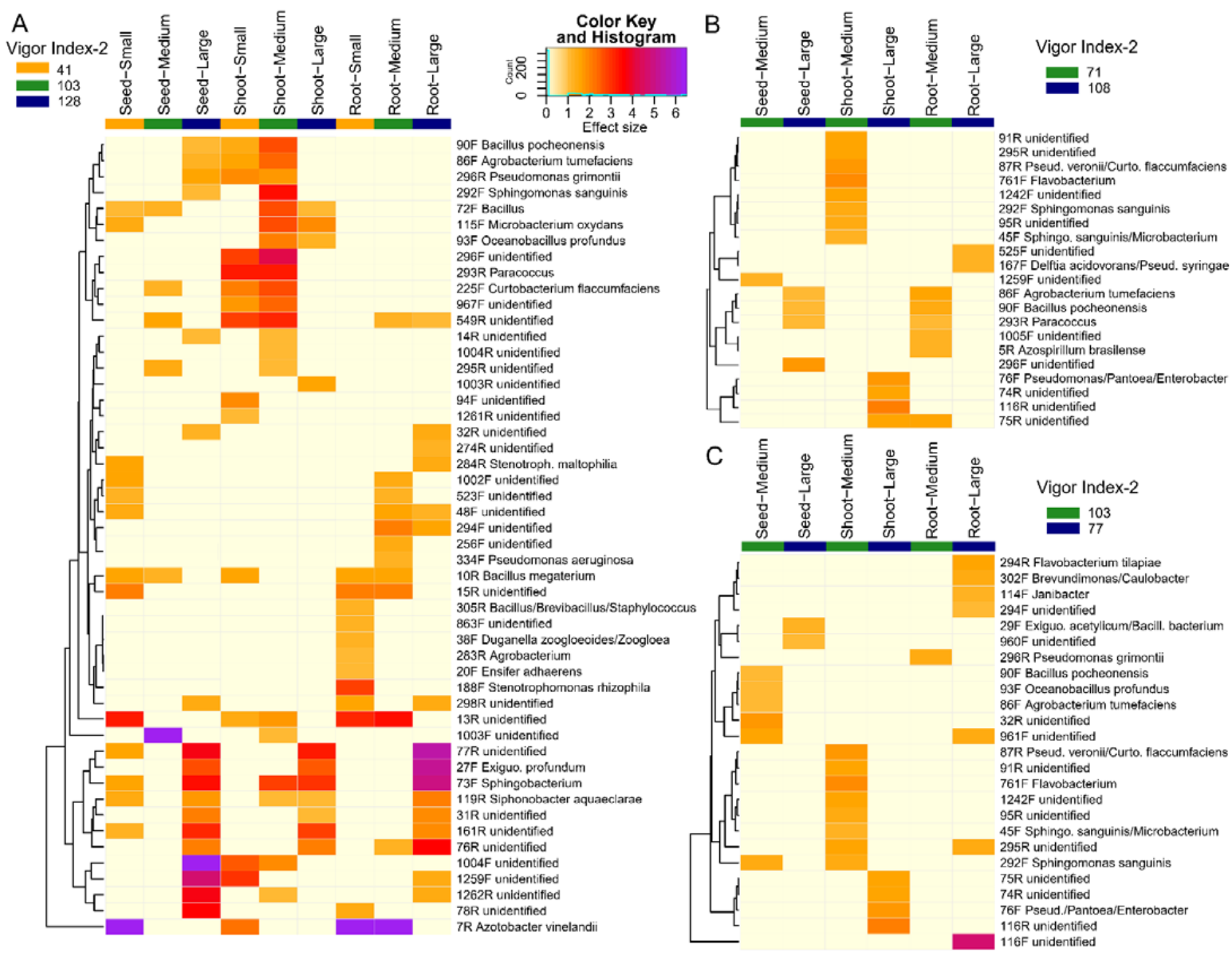

Figure 5. Heatmap of high effect (ALDEx) TRFs alongside probable taxonomic identities. TRFs of each seed category along with their respective tissue types (seed, shoot and root) and vigor index-2 values. The color gradient displays the strength of the ALDEx effect sizes, higher effect sizes indicate greater differences in TRF intensity between sample types. Variety 1 (A), Variety 2 (B), Variety 3 (C).

In Variety 1 (Figure 5A), large seeds had a greater number of TRF differences than small or medium, and seven TRFs (77R/31R/161R/76R unidentified bacteria, 27F Exiguobacterium, 73F Sphingobacterium, 119R Siphonobacter) were found in both the shoots and roots of plants grown from larger seeds. There were more common TRFs between Shoot-Small and Shoot-Medium plants, than Shoot-Large plants. Unsurprisingly, the roots of plants grown from all three seed sizes had different TRF communities from the shoot or seed endophytes, except for the seven TRFs mentioned above. Azobacter vinelandii was the most dominant bacteria in the small seed and this was also dominant in shoots and roots derived from this seed size (Figure $5 \mathrm{~A}$ ).

In Variety 2, there were $5 \mathrm{TRF}$ separating medium and large seeds (1259F and 296F unidentified bacteria, 86F Agrobacterium, 90F Bacillus, 293R Paracoccus), but none of these were significantly separated in tissues grown from the same seed. Fourteen TRFs separated tissue types and seed sizes, with one TRF (75R unidentified bacterium) that was found in Shoot-Large and Root-Medium samples (Figure 5B).

In Variety 3, there were seven TRFs separating medium (90F Bacillus, 93F Oceanobacillus, 86F Agrobacterium, 292F Sphingomonas, and 32R/961F unidentified bacteria) and large (29F Exiguobacterium /Bacillaceae, 960F unidentified bacterium) seeds. Out of the samples, 292F Sphingomonas was the only significant TRF in medium seeds that was also found in medium shoot samples. There was one TRF, 296R Pseudomonas, that was found in Root-Medium, and five different TRFs that were only found in Root-Large tissues (294R Flavobacterium, 302F Brevundimonas/Caulobacter, 114F Janibacter, 294F and 116F unidentified bacteria) (Figure 5C). The taxonomic identities are probable, as we used in-silico analysis to identify the TRFs. 


\subsection{Microbial Richness and Diversity}

The total number of TRFs ranged from 15 to 140 among all the seed hybrids tested in this study. As TRF diversity (number) increased, the seed vigor decreased (Figure 6). The total TRFs in each seed category within and across varieties showed a strong negative relationship with seed vigor (correlation " $\rho$ " -0.49 with $p<0.05$ ), having V1-Root-Medium seeds as an outlier. The microbial TRF richness and alpha diversity was compared by calculating the Shannon, Simpson and Fisher values of each variety, with each point being colored by both Vigor-Index values. Both VI-1 and VI-2 plots were identical (Figure 6; data not shown for VI-1), and Fisher's richness was identical to Observed richness. The large and medium seeds in V1 have lower microbial richness and diversity, and high seedling Vigor index values in comparison to seedlings grown from smaller seeds (V1-Md2 being an exception to the pattern). In V2, half of the large seeds had lower microbial diversity and high VI values, and all medium seeds and the remaining large seeds had higher TRF richness and low vigor index values. The seed size of V3 showed the opposite pattern, where larger seeds had higher microbial richness and diversity, with V3-Lg3 being an outlier to the pattern. These results indicate that the richness and diversity of the microbiome has a significant contribution to the seed health and vigor, and it varies with seed size as well the genetic makeup of the seeds (Figure 6).

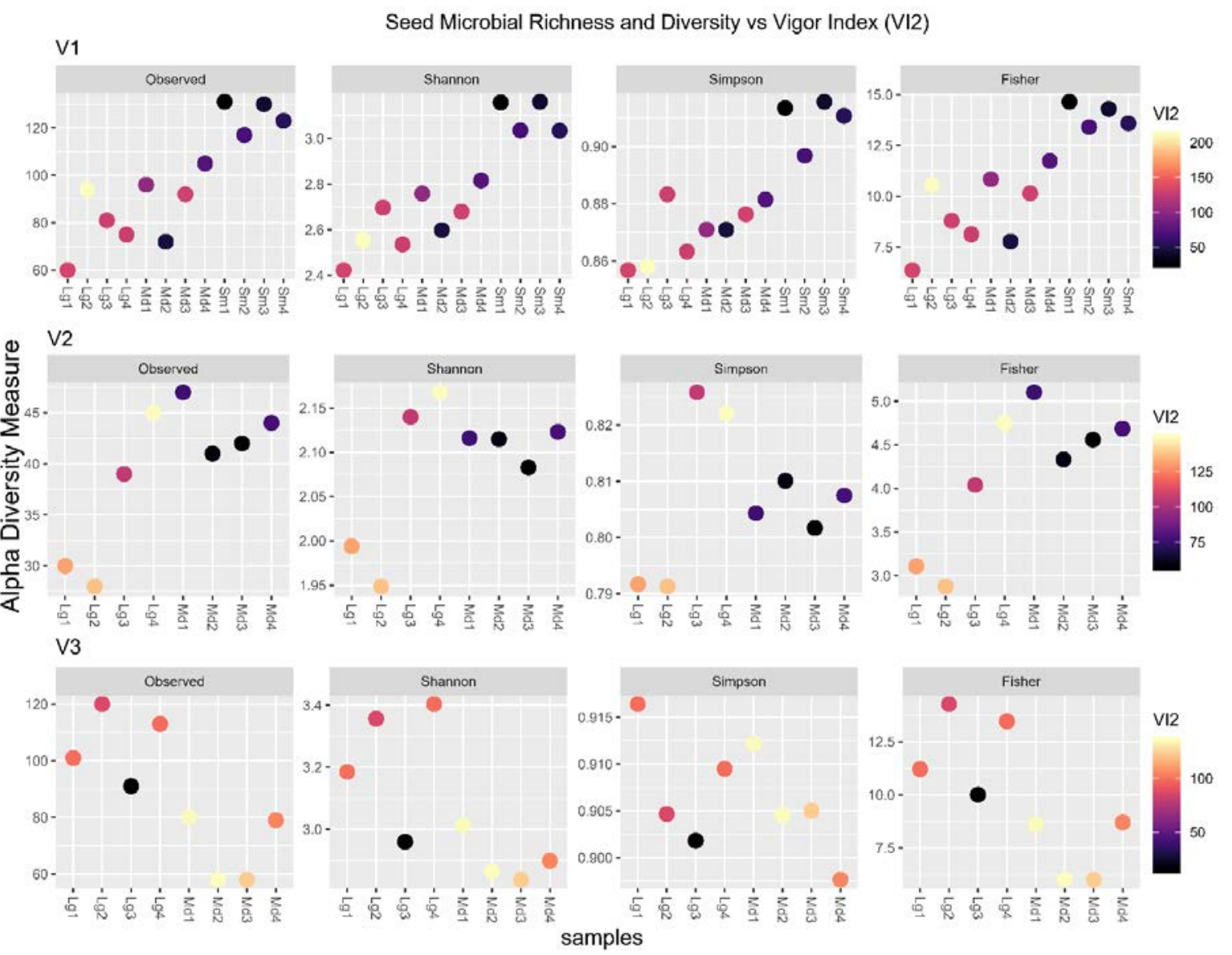

Figure 6. Seed microbial diversity and richness indices of different seed sizes in Varieties 1, 2, and 3; points are colored by Vigor Index-2. Sm1-4, Md1-4, and Lg1-4 are TRF replicates of Small, Medium, and Large size seeds, respectively.

\subsection{Interaction of Seed Chemistry, Microbiome and Vigor}

V1-S seeds showed higher $\mathrm{Cl}, \mathrm{K} \%, \mathrm{~S} \%$, whereas V1-M seeds had relatively higher $\mathrm{Fe}$, ash, germination \% (G\%) compared to V1-S, and in V1-L seeds there were higher levels of $\mathrm{Mg} \%, \mathrm{P} \%$ which likely contributed to their separation (Figure 7A). The average seed weight (Av.E.Wt), dry shoot weight 
(Dr.H.Wt), and Vigor Index-1 and 2 (VI-1 and VI-2) are the only significant plant biometric parameters, all associated with large seeds of Variety 1 (Figure 7A). In $\mathrm{V} 2$ seeds, $\mathrm{pH}, \mathrm{Al}$, protein \% (chemical factors), G\%, VI-1, VI-2 and dry shoot weight (biometric parameters) separated medium and large seeds (Figure 7B). TRFs 1005, 1049, and 1259 significantly (high ALDEx effect size) contributed in separating the two seed sizes (Figure 5). Of these, $\mathrm{pH}$, and $\mathrm{Al}$ were associated with $\mathrm{V} 2-\mathrm{M}$, and protein $\%, \mathrm{G} \%$, VI-1, VI-2 and dry shoot weights were seen in V2-L seeds. In V3 seeds, Al (chemical factor), G\%, VI-1, VI-2 and dry shoot and root weights, Average Seed Weight (biometric parameters; Figure 7C), and TRFs 116, and 294 significantly contributed in differentiating medium and large seeds. Higher aluminum was seen in V3-M seeds and all other significant parameters were seen in V3-L seeds (Figure 7C).
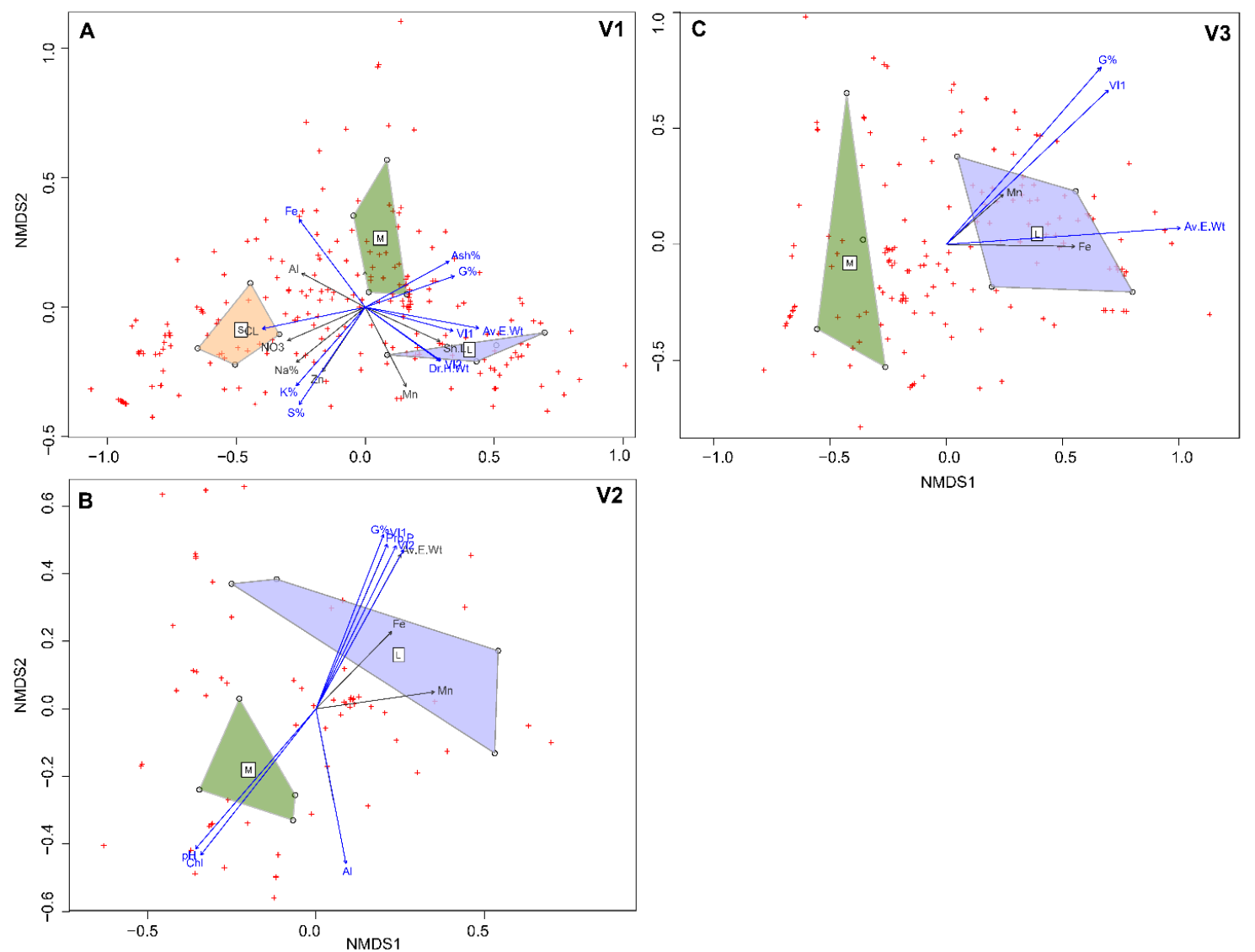

Figure 7. NMDS scatterplot showing significant seedling biometrics, kernel chemistry, and TRFLP profiles of different seed sizes among 3 hybrids: (A) Variety 1 (V1), (B) Variety 2 (V2), and (C) Variety 3 (V3). Individual TRFs are shown with red "+" symbols, vectors represent significant plant biometric or kernel chemical parameters; blue vectors are significant to the NMDS ordination and the stress values are $<0.2$ for each plot.

\section{Discussion}

This study examined how the seed sizes of three commonly grown corn hybrids (P9998AMXT, P0157AMXT, and DKC48-56 RIB) impact seed germination and seedling vigor under a controlled greenhouse environment. Additionally, we assessed the interactions of seed size, seedling vigor, seed nutrition, and changes in seed/seedling microbiome after germination. Several other researchers from various locations confirmed that low vigor seeds were responsible for reducing overall crop growth [27-29]. We had speculated that the lower competitive ability of low vigor seedling were associated with reduction in productivity and our results confirm this assumption [30]. Our experimental data shows that there are effects of seed size and hybrid variety on variations in seedling vigor, the levels of seed nutritional elements, and microbial abundance and diversity. 
A solid positive relationship was found between seed vigor capacity and biometric parameters such as germination percentage, seedling length, and dry weight and vigor indices. These observations agree with previous work where plant height, stem diameter, and leaf area index of high vigor seeds within a seeding row resulted in a better development of a plant population [30].

Seed quality usually has an impact on the seedling vigor and its establishment. The vigor indices of small seeds are significantly lower than the larger seeds within the same seed lot. Previous studies also shed light on the present observation where seed size, seed quality is the primary factor affecting seed germination, seedling establishment, and subsequent growth and development $[29,31]$. Seed viability is the ability of the seed to germinate under optimal conditions, whereas vigor is its ability to emerge uniformly even under adverse environmental conditions in the field. These terms are often used interchangeably and incorrectly. Low-vigor corn seeds emerge less uniformly than high-vigor seeds [32], and the delay in emergence results in underdevelopment at all the stages of plant growth as compared to high vigor seeds. This directly influences the seedling's competitive ability for light, water, and nutrients. Irregularities in plant development within a population results in decreased grain yield [31]. Practices aiming to increase uniform population development will contribute to maximizing final yields. Höfs et al. [33], and others [32] have proven that the plants originating from seeds with high physiological potential had higher plant biomass production and grain yield.

There was a larger variation in the mineral content within each variety: iron and manganese were lower in small seeds and higher in large seeds in all varieties. Small seeds of Variety 1 (P9998AMXT) had higher sulphur, potassium, magnesium, sodium, nitrate nitrogen, zinc, and chloride, but had lower ash, iron, and manganese compared to medium and large seed lots. The aluminum content in Variety 2 (P0157AMXT) was higher in medium seeds compared to large but no difference was observed in Variety 3 (DKC48-56 RIB). These observations indicate that size and the proportion of minerals are not directly associated with all seed sizes across varieties. These variabilities are most likely related to the nutritional variability in the soil where the parent plants were grown and inconsistent environmental conditions during plant development including heat [34] and water stress [35]. Nutritional stability, composition, and the weather conditions during the seed formation strongly influence the uniformity of the seeds produced by the mother plant $[35,36]$. This in turn influences specific biochemical functions that affect seedling vigor [37]. Venuto et al. [38] showed that seed weight significantly influences germination, seedling vigor and seasonal yield performance of annual ryegrass cultivars. The extent that reserved food in seeds supports seedling establishment is not fully understood, nor is the variation in different varieties and the sizes of their seeds within the same variety/hybrids, since the small and large seeds tend to have different amounts and compositions of nutritional reserves [36].

Seed size, density, the degree of filling, and nutrient content are reported as key indicators of seedling vigor in cotton [39,40], and Begna et al. [41] reported that seed size and shape impacts germination characteristics of maize hybrids. Rajjou et al. [18] stated that key determinants of successful germination and seed vigor relate to the amount of stored proteins, the quality of mRNA built up during embryo maturation, and the hormonal constitution of a seed. Eggert and Wirén [36] and Zhao et al. [42] indicated that boron nutrition in oil seed rape is very important at all the stages of seedling development. Boron deficiency leads to the production of seeds with damaged embryos, lower vigor, and weaker germination rates that reduces overall seed quality. Boron content in all three hybrids tested in this study were linked with their vigor capacities, even though the levels are not statistically significant among size categories. These specific nutritional deficiencies can be corrected in high vigor seeds through the external supply of the deficient nutrient to obtain their maximum vigor potential [36].

This study showed significant differences in the microbial profile of seed, root, and shoot of different seed size groups within hybrids. Variety 2 seeds had similar microbiomes and distinct root and shoot microbiomes after seed germination, but Variety 3 showed the opposite trend with a convergence in microbiome similarity after germination. Variety 1 showed separation in the seeds of all three sizes, but root and shoot tissues grown from small and medium seeds showed a convergence 
in bacterial communities. Germinating seeds interact with soil microbes, and these contribute in varying degrees to the developing seedling microbiome [43-45] just as much as the seed's origin and genetics [14,46-48]. The microbial colonization of the roots and shoots in this experiment is mainly based on seed microbiome and was found to be cultivar related when differences in soil factors were removed by using the same growing medium. Microbial diversity was found to have a strong negative correlation with seed vigor (VI-1 and VI-2), where seed lots with higher microbial diversity generally exhibited poorer seed vigor. Even though there are many TRFs found in this study, a small fraction appeared to differentiate between the tissue types and seed sizes.

Although the current study listed probable key microbial and nutritional factors that may be associated with high or low vigor seeds, it is highly likely that the developmental conditions of the mother plant, as well as post-harvest management practices, may have largely contributed to the differences in a seed's nutritional and microbiome composition [49]. The seed microbiome has a vital effect on seedling germination and development, so it is important that seeds harbor a healthy microbiome for better plant health and crop productivity [50-52]. Previous researchers proposed the possibility of improving low productive soil through selective microbial inoculation $[53,54]$. Kandasamy et al. [23] showed that the microbiome of a low productive soil could be changed by introducing key microbial players found in high productive soils. This knowledge will be helpful in selecting seed specific microbe(s) while attempting to improve the yield potential of low vigor seeds after planting.

We observed that size, nutrition, and microbial diversity of seeds within the same seed lot affect seedling vigor, but the observed relationship was not always positively correlated. Among the 3 varieties tested, the vigor and nutritional components of seeds in Varieties 1 and 2 showed a positive relationship with seed size (larger seeds had better vigor) whereas Variety 3 showed a negative relationship (medium seeds had better vigor). Seed vigor and proper seedling establishment is an integral part of profitable and sustainable crop production since it influences timing and uniformity of seedling emergence. This will indirectly impact many aspects of crop production that determine crop input requirements, cost effectiveness, and directly affect the yield and marketing quality of a crop. Any management practices during later stages of crop development will not compensate for the losses that occur during early development.

\section{Conclusions}

This study describes the relationships between seed size, vigor, nutritional composition, and microbial profiles of seeds from three common Canadian hybrid varieties. It was found that larger seeds had higher seedling vigor in two of the three tested varieties. Depending on the proportions of seed sizes within a lot, this could result in potential yield losses of up to $25 \%$. We do not know whether these patterns are seen in other varieties in the Canadian or international seed markets, but this study promotes the testing of larger seed lots of different hybrid varieties, as well as the development of remedial actions to equalize seed vigor within varieties.

Author Contributions: S.K. conceived and designed the study. S.K. and D.G., carried out the experiment, collected data. S.K. and N.W. analyzed the data and S.K. wrote the manuscript. N.W., G.L., G.P. Review and editing, S.K., G.P., S.S., S.A. and G.L. All Authors have read and agreed to the published version of the manuscript.

Funding: D.G. was the recipient of Undergraduate Student Research Awards from Natural Sciences and Engineering Research Council. We also greatly appreciate the Funding provided by Agriculture Innovation Program (AIP) through Industry-led Research and Development Stream (AIP-P242) and Eco-Canada, those are vital for the successful completion of this project.

Acknowledgments: We greatly acknowledge the support of growers for participating in the AIP research program and appreciate the help of the A \& L Biologicals technical staffs and coop students in sampling and lab experimentation.

Conflicts of Interest: The authors declare to have no conflict of interest. 


\section{References}

1. Dent, K.C.; Stephen, J.R.; Finch-Savage, W.E. Molecular profiling of microbial communities associated with seeds of Beta vulgaris subsp. vulgaris (sugar beet). J. Microbiol. Methods 2004, 56, 17-26. [CrossRef]

2. Carter, P.R. Selecting Corn Hybrids; University of Wisconsin-Extension: Madison, WI, USA, 1992; p. 3265.

3. Kaydan, D.; Yagmur, M. Germination, seedling growth and relative water content of shoot in different seed sizes of triticale under osmotic stress of water and $\mathrm{NaCl}$. Afr. J. Biotechnol. 2008, 7, 2862-2868.

4. Biçer, B.T. The effect of seed size on yield and yield components of chickpea and lentil. Afr. J. Biotechnol. 2009, 8, 1482-1487.

5. Stougaard, R.N.; Xue, Q. Quality versus quantity: Spring wheat seed size and seeding rate effects on Avena fatua interference, economic returns and economic thresholds. Weed Res. 2005, 45, 351-360. [CrossRef]

6. Royo, C.; Ramdani, A.; Moragues, M.; Villegas, D. Durum Wheat under Mediterranean Conditions as Affected by Seed Size. J. Agron. Crop Sci. 2006, 192, 257-266. [CrossRef]

7. Stougaard, R.N.; Xue, Q. Spring wheat seed size and seeding rate effects on yield loss due to wild oat (Avena fatua) interference. Weed Sci. 2004, 52, 133-141. [CrossRef]

8. Demirlicakmak, A.; Kaufmann, M.L.; Johnson, L.P. V The influence of seed size and seeding rate on yield and yield components of barley. Can. J. Plant Sci. 1963, 43, 330-337. [CrossRef]

9. Mian, A.R.; Nafziger, E.D. Seed Size Effects on Emergence, Head Number, and Grain Yield of Winter Wheat. J. Prod. Agric. 1992, 5, 265-268. [CrossRef]

10. Adebisi, M.A.; Okelola, F.S.; Ajala, M.O.; Kehinde, T.O.; Daniel, I.O.; Ajani, O.O. Evaluation of Variations in Seed Vigour Characters of West Afr. Rice (Oryza sativa L.) Genotypes Using Multivariate Technique. Am. J. Plant Sci. 2013, 4, 356-363. [CrossRef]

11. Wen, D.; Hou, H.; Meng, A.; Meng, J.; Xie, L.; Zhang, C. Rapid evaluation of seed vigor by the absolute content of protein in seed within the same crop. Sci. Rep. 2018, 8, 5569. [CrossRef]

12. Milosevic, M.; Vujakovic, M.; Karagic, D. Vigour tests as indicators of seed viability. Genetika 2010, 42, $103-118$. [CrossRef]

13. Zhang, A.; Liu, C.; Chen, G.; Hong, K.; Gao, Y.; Tian, P.; Peng, Y.; Zhang, B.; Ruan, B.; Jiang, H.; et al. Genetic analysis for rice seedling vigor and fine mapping of a major QTL $q S S L 1 b$ for seedling shoot length. Breed. Sci. 2017, 67, 307-315. [CrossRef] [PubMed]

14. Rybakova, D.; Mancinelli, R.; Wikström, M.; Birch-Jensen, A.-S.; Postma, J.; Ehlers, R.-U.; Goertz, S.; Berg, G. The structure of the Brassica napus seed microbiome is cultivar-dependent and affects the interactions of symbionts and pathogens. Microbiome 2017, 5, 104. [CrossRef] [PubMed]

15. Biswas, J.C.; Ladha, J.K.; Dazzo, F.B.; Yanni, Y.G.; Rolfe, B.G. Rhizobial Inoculation Influences Seedling Vigor and Yield of Rice. Agron. J. 2000, 92, 880-886. [CrossRef]

16. Gholami, A.; Shahsavani, S.; Nezarat, S. The effect of plant growth promoting rhizobacteria (PGPR) on germination, seedling growth and yield of maize. Int. J. Agric. Biosyst. Eng. 2009, 3, 35-40.

17. Nonogaki, H.; Bassel, G.W.; Bewley, J.D. Germination-Still a mystery. Plant Sci. 2010, 179, 574-581. [CrossRef]

18. Rajjou, L.; Duval, M.; Gallardo, K.; Catusse, J.; Bally, J.; Job, C.; Job, D. Seed Germination and Vigor. Annu. Rev. Plant Biol. 2012, 63, 507-533. [CrossRef]

19. Malhi, S.S.; Raza, M.; Schoenau, J.J.; Mermut, A.R.; Kutcher, R.; Johnston, A.M.; Gill, K.S. Feasibility of boron fertilization for yield, seed quality and B uptake of canola in northeastern Saskatchewan. Can. J. Soil Sci. 2003, 83, 99-108. [CrossRef]

20. Abdul-Baki, A.A.; Anderson, J.D. Vigor Determination in Soybean Seed by Multiple Criteria. Crop Sci. 1973, 13, 630. [CrossRef]

21. Marchesi, J.R.; Sato, T.; Weightman, A.J.; Martin, T.A.; Fry, J.C.; Hiom, S.J.; Wade, W.G. Design and evaluation of useful bacterium-specific PCR primers that amplify genes coding for bacterial 16S rRNA. Appl. Environ. Microbiol. 1998, 64, 795-799.

22. Osborn, A.M.; Moore, E.R.B.; Timmis, K.N. An evaluation of terminal-restriction fragment length polymorphism (T-RFLP) analysis for the study of microbial community structure and dynamics. Environ. Microbiol. 2000, 2, 39-50. [CrossRef] [PubMed] 
23. Kandasamy, S.; Liu, E.Y.R.; Patterson, G.; Saldias, S.; Ali, S.; Lazarovits, G. Introducing key microbes from high productive soil transforms native soil microbial community of low productive soil. Microbiologyopen 2019, 8, e895. [CrossRef] [PubMed]

24. Oksanen, J.; Blanchet, F.G.; Kindt, R.; Legendre, P.; Minchin, P.; O’Hara, R.B.; Simpson, G.; Solymos, P.; Stevenes, M.H.H.; Wagner, H. vegan: Community Ecology Package, R package version 2.5-5; 2019. Available online: https://CRAN.R-project.org/package=vegan (accessed on 15 November 2019).

25. Fernandes, A.D.; Macklaim, J.M.; Linn, T.G.; Reid, G.; Gloor, G.B. ANOVA-Like Differential Gene Expression Analysis of Single-Organism and Meta-RNA-Seq. PLoS ONE 2013, 8, e67019. [CrossRef] [PubMed]

26. Warnes, G.R.; Bolker, B.; Bonebakker, L.; Gentleman, R.; Liaw, W.H.A.; Lumley, T.; Maechler, M.; Magnusson, A.; Moeller, S.; Schwartz, M.; et al. gplots: Various R Programming Tools for Plotting Data, $\mathrm{R}$ package version 3.0.1.1; 2019. Available online: https://CRAN.R-project.org/package=gplots (accessed on 15 November 2019).

27. Adebisi, M.A.; Kehinde, T.O.; Salau, A.W.; Okesola, L.A.; Porbeni, J.B.O.; Esuruoso, A.O.; Oyekale, K.O. Influence of different seed size fractions on seed germination, seedling emergence and seed yield characters in tropical soybean (Glycine max L. Merrill). Int. J. Agric. Res. 2013, 8, 26-33. [CrossRef]

28. Manonmani, V.; Vanangamudi, K.; RS, V.R. Effect of seed size on seed germination and vigour in Pongamia pinnata. J. Trop. For. Sci. 1996, 9, 1-5.

29. Ambika, S.; Manonmani, V.; Somasundar, G. Review on Effect of Seed Size on Seedling Vigour and Seed Yield. Res. J. Seed Sci. 2014, 7, 31-38. [CrossRef]

30. Mondo, V.H.V.; Cicero, S.M.; Dourado-Neto, D.; Pupim, T.L.; Dias, M.A.N. Seed vigor and initial growth of corn crop. J. Seed Sci. 2013, 35, 64-69. [CrossRef]

31. Finch-Savage, W.E. Influence of seed quality on crop establishment, growth and yield. In Seed Quality: Basic Mechanisms and Agricultural Implications; Basra, A.S., Ed.; Food Products Press: New York, NY, USA, 1995; pp. 361-384.

32. Egli, D.B.; Rucker, M. Seed Vigor and the Uniformity of Emergence of Corn Seedlings. Crop Sci. 2012, $52,2774$. [CrossRef]

33. Hofs, J.-L.; Schoeman, A.; Vaissayrel, M. Effect of Bt cotton on arthropod biodiversity in South Afr. cotton fields. Commun. Agric. Appl. Biol. Sci. 2004, 69, 191.

34. Gaur, P.M.; Samineni, S.; Krishnamurthy, L.; Varshney, R.K.; Kumar, S.; Ghanem, M.E.; Beebe, S.E.; Rao, I.M.; Chaturvedi, S.K.; Basu, P.S. High temperature tolerance in grain legumes. Legum. Perspect. 2015, 7, $23-24$.

35. Nemeskéri, E.; Molnár, K.; Rácz, C.; Dobos, A.; Helyes, L. Effect of Water Supply on Spectral Traits and Their Relationship with the Productivity of Sweet Corns. Agronomy 2019, 9, 63.

36. Eggert, K.; von Wirén, N. The role of boron nutrition in seed vigour of oilseed rape (Brassica napus L.). Plant Soil 2015, 402, 63-76. [CrossRef]

37. Hänsch, R.; Mendel, R.R. Physiological functions of mineral micronutrients ( $\mathrm{Cu}, \mathrm{Zn}, \mathrm{Mn}, \mathrm{Fe}, \mathrm{Ni}, \mathrm{Mo}, \mathrm{B}, \mathrm{Cl})$. Curr. Opin. Plant Biol. 2009, 12, 259-266. [CrossRef] [PubMed]

38. Venuto, B.C.; Redfearn, D.D.; Pitman, W.D.; Alison, M.W. Seed variation among annual ryegrass cultivars in south-eastern USA and the relationship with seedling vigour and forage production. Grass Forage Sci. 2002, 57, 305-311.

39. Nelson, D.R.; Mele, P.M. Subtle changes in rhizosphere microbial community structure in response to increased boron and sodium chloride concentrations. Soil Biol. Biochem. 2007, 39, 340-351. [CrossRef]

40. Nelson, E.B. The seed microbiome: Origins, interactions, and impacts. Plant Soil 2018, 422, 7-34.

41. Begna, S.H.; Hamilton, R.I.; Dwyer, L.M.; Stewart, D.W.; Cloutier, D.; Assemat, L.; Foroutan-pour, K.; Smith, D.L. Morphology and yield response to weed pressure by corn hybrids differing in canopy architecture. Eur. J. Agron. 2001, 14, 293-302.

42. Zhao, Z.; Wu, L.; Nian, F.; Ding, G.; Shi, T.; Zhang, D.; Shi, L.; Xu, F.; Meng, J. Dissecting Quantitative Trait Loci for Boron Efficiency across Multiple Environments in Brassica napus. PLoS ONE 2012, 7, e45215. [CrossRef]

43. Adams, P.D.; Kloepper, J.W. Effect of host genotype on indigenous bacterial endophytes of cotton (Gossypium hirsutum L.). Plant Soil 2002, 240, 181-189. [CrossRef]

44. Truyens, S.; Weyens, N.; Cuypers, A.; Vangronsveld, J. Changes in the population of seed bacteria of transgenerationally Cd-exposed Arabidopsis thaliana. Plant Biol. 2012, 15, 971-981. 
45. Hardoim, P.R.; van Overbeek, L.S.; Berg, G.; Pirttilä, A.M.; Compant, S.; Campisano, A.; Döring, M.; Sessitsch, A. The hidden world within plants: Ecological and evolutionary considerations for defining functioning of microbial endophytes. Microbiol. Mol. Biol. Rev. 2015, 79, 293-320. [CrossRef] [PubMed]

46. Berg, G.; Smalla, K. Plant species and soil type cooperatively shape the structure and function of microbial communities in the rhizosphere. FEMS Microbiol. Ecol. 2009, 68, 1-13. [CrossRef]

47. Cardinale, M.; Grube, M.; Erlacher, A.; Quehenberger, J.; Berg, G. Bacterial networks and co-occurrence relationships in the lettuce root microbiota. Environ. Microbiol. 2014, 17, 239-252. [CrossRef] [PubMed]

48. Lundberg, D.S.; Lebeis, S.L.; Paredes, S.H.; Yourstone, S.; Gehring, J.; Malfatti, S.; Tremblay, J.; Engelbrektson, A.; Kunin, V.; del Rio, T.G.; et al. Defining the core Arabidopsis thaliana root microbiome. Nature 2012, 488, 86-90. [CrossRef] [PubMed]

49. Adebisi, M.; Ojo, D.K. Effect of Genotypes on Soyabean Seed Quality Development under West Afr. Rainfed Conditions. Pertanika J. Trop. Agric. Sci. 2001, 24, 139-146.

50. Jones, N. Food fuelled with fungi. Nature 2013, 504, 199. [CrossRef] [PubMed]

51. Vujanovic, V.; Germida, J. Seed endosymbiosis: A vital relationship in providing prenatal care to plants. Can. J. Plant Sci. 2017, 97, 972-981. [CrossRef]

52. Sessitsch, A.; Mitter, B. 21st century agriculture: Integration of plant microbiomes for improved crop production and food security. Microb. Biotechnol. 2014, 8, 32-33. [CrossRef]

53. Wubs, E.R.J.; van der Putten, W.H.; Bosch, M.; Bezemer, T.M. Soil inoculation steers restoration of terrestrial ecosystems. Nat. Plants 2016, 2, 16107. [CrossRef]

54. Rodríguez-Caballero, G.; Caravaca, F.; Fernández-González, A.J.; Alguacil, M.M.; Fernández-López, M.; Roldán, A. Arbuscular mycorrhizal fungi inoculation mediated changes in rhizosphere bacterial community structure while promoting revegetation in a semiarid ecosystem. Sci. Total Environ. 2017, 584, 838-848. [CrossRef]

(C) 2020 by the authors. Licensee MDPI, Basel, Switzerland. This article is an open access article distributed under the terms and conditions of the Creative Commons Attribution (CC BY) license (http://creativecommons.org/licenses/by/4.0/). 